\title{
WIND FARMS AND AVIATION
}

\author{
Andrej Novák \\ University of Žilina, Department of Air Transport, Univerzitna 1, 01026 Žilina, Slovakia \\ E-mail: Andrej.Novak@fpedas.uniza.sk
}

Received 19 January 2009, accepted 5 May 2009

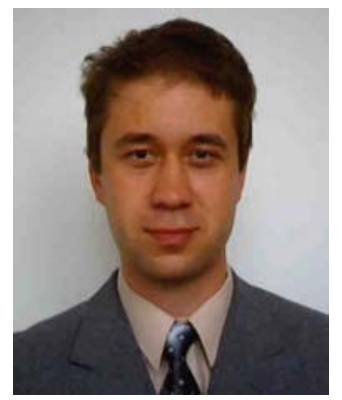

Andrej NOVÁK, PhD

A member of the staff of the Department of Air Transport, Faculty of Operation and Economics of Transport and Communications, at the University of Žilina. In 1998 he earned a master's degree in radio communication technique from the Faculty of Electrical Engineering at the University of Žilina (Slovakia). Major fields of interest are: CNS/ATM, transport and traffic system analysis, wind farms and CNS systems.

\begin{abstract}
Wind is an increasingly important source of energy for the Slovak Republic. It is exploited by the use of turbines to generate electricity. Because of their physical size, in particular their height, wind farms can have an effect on aviation. Additionally, rotating wind turbine blades may have an impact on certain aviation operations, particularly those involving radar.
\end{abstract}

Keywords: wind farm, radar theory, air traffic management, communication navigation and surveillance.

\section{Introduction}

There are two types of radar used for air traffic control and air defence control and surveillance: primary surveillance radar (PSR) and secondary surveillance radar (SSR).

Primary radar operates by radiating electromagnetic energy and detecting the presence and character of the echo returned from reflecting objects. Comparison of the returned signal with that transmitted yields information about the target, such as location, size, and whether it is in motion relative to the radar.

Primary radar cannot differentiate between types of objects; its energy will bounce off any reflective surface in its path. Moreover, air traffic control primary radar has no means of determining the height of an object, whereas modern air defence radars do possess this capability, using electronic beam control techniques.

For SSR, the ground station emits "interrogation" pulses of radio frequency (RF) energy via the directional beam of a rotating antenna system. When the antenna beam is pointing in the direction of an aircraft, airborne equipment, known as a transponder, transmits a reply to the interrogation. The reply is detected by the ground station and processed by a plot extractor.

The plot extractor measures the range and bearing of the aircraft and decodes the replies of the aircraft to determine the aircraft's flight level and identity (Mode C operation).

In the Slovak Republic, all aircraft flying in controlled airspace must carry a SSR transponder. Some light aircraft do not, and aircraft that do carry them may not have them switched on, in which case they will not be visible to SSR. Most ATC units are equipped with both primary and SSR, but increasingly, radar services are provided using SSR only.

From 2008 onwards, a new type of SSR called Mode $S$ will begin to be introduced in SR airspace. Mode $\mathrm{S}$ is a development of classical SSR that overcomes many of the current limitations of the SSR system. It is proposed, subject to formal consultation, to introduce Mode $\mathrm{S}$ initially in 2008 with a second phase of regulatory changes in 2008. In addition, it is proposed that the requirements for the carriage and operation of transponders will be significantly extended in conjunction with the Mode $\mathrm{S}$ plans for 2009. 


\section{Radar functions}

\subsection{Air traffic control (ATC)}

Radar performs two functions for air traffic control: a) airport surveillance radar allows air traffic controllers to provide air traffic services to aircraft in the vicinity of an airport. This service may include vectoring aircraft to land, providing radar service to departing aircraft, or providing service to aircraft either transiting through the area or in the airfield circuit;

b) en route (or area) radar is used to provide services to traffic in transit. This includes commercial airliners and military traffic. Area radar has a longer range than airport radar, particularly at high altitudes.

\subsection{Air defence}

Air defence radar is used in two ways. On the one hand, it performs a function similar to its ATC counterparts, being used by air defence controllers to provide control services to military (usually air defence) traffic. It is, however, also used to monitor all air traffic activity within the Slovak Republic and its approaches to produce a recognised air picture (RAP) with the aim of preserving the integrity of SR airspace through air policing. The RAP is produced by allocating track identities to each radar return (or "plot") of interest. A radar plot can often fade from a radar display for a period of time due to a number of factors, but the track identity will remain, indicating that the associated plot is actually still present (Lewis 2001)

\subsection{Meteorological radar}

Meteorological radar uses electromagnetic (EM) energy to monitor weather conditions (predominantly cloud and precipitation) at low altitudes to assist weather forecasting. Wind profiling radar is used to measure wind speed at different altitudes.

\section{The nature of the impact of wind turbines}

\section{Masking}

This is the main anticipated effect on air defence surveillance radar. Such radar works at high radio frequencies and therefore depends on a clear "line of sight" to the target object for successful detection. It follows that any geographical feature or structure lying between the radar and the target will cause a shadowing or masking effect; military aircraft wishing to avoid detection readily exploits indeed this phenomenon. It is possible that, depending on their size, wind turbines may cause shadowing effects. Such effects may be expected to vary, depending upon the turbine dimensions, the type of transmitting radar, and the aspect of the turbine relative to it.

The Met Office is also concerned with the effect of masking on their sensors. Met Office radar looks at a relatively narrow altitude band that is as near to the earth's surface as possible. Due to the sensitivity of the radar, wind turbines, if they are poorly sited, have the potential to significantly reduce weather radar performance (Wind ... 2001).

\section{Radar returns/radar clutter}

Radar returns may be received from any radarreflective surface. In certain geographical areas, or under particular meteorological conditions, radar performance may be adversely affected by unwanted returns, which may mask those of interest. Such unwanted returns are known as radar clutter. Clutter is displayed to a controller as "interference" and is primarily a problem for air defence and airport radar operators because it occurs more often at lower altitudes.

For an airport radar operator, a wind turbine or turbines in the vicinity of his airfield can present operational problems. If the turbine generates a return on his radar screen and the controller recognises it as such, he may choose to ignore it. However, such unwanted returns may obscure others that genuinely represent aircraft, thereby creating a potential hazard to flight safety. This may be of particular concern in poor weather.

A structure, which permanently paints on the radar in the same position, is preferable to one that only presents an intermittent return. This is because an intermittent return is more likely to represent a manoeuvring or unknown aircraft, obliging the controller to act accordingly. With this in mind, it is possible that aviators and radar operators could work safely with one or perhaps two turbines in the vicinity of an aerodrome. Of greater concern is the prospect of a proliferation of turbines, which could potentially saturate an airfield radar picture, making safe flying operations difficult to guarantee.

Several turbines in close proximity to each other and painting on radar could present particular difficulties for long-range air surveillance radar. A rotating wind turbine is likely to appear on a radar display intermittently (studies suggest a working figure to be one paint every six sweeps).

Multiple turbines, in proximity to each other, will present several returns during every radar sweep, causing a "twinkling" effect. As these will appear at slightly different points in space, the radar system may interpret them as being one or more moving objects and a surveillance radar will then initiate a "track" on the returns. This can confuse the system and may eventually overload it with too many tracks. Measures can be taken to mitigate this problem, and they are amplified in Section D4, but these too have their drawbacks (Knill 2002).

\section{5. "Scattering", "refraction" and/or "false returns"}

Scattering occurs when the rotating wind turbine blades reflect or refract radar waves in the atmosphere. These are then subsequently absorbed either by the 
source radar system or another system and can then give false information to that system. It may affect both primary and SSR radars. This effect is as yet not quantified but is certainly possible. It has, for example, been witnessed at Copenhagen Airport as a result of the Middelgrunden Offshore Wind Farm.

The possible effects are:

a) multiple, false radar returns being displayed to the radar operator: blade reflections may be displayed at the controller's console as spurious radar contacts;

b) radar returns from genuine aircraft being displayed, but in an incorrect location (range, azimuth, or both);

c) garbling or loss of SSR information.

The SSR code allocated to an aircraft may not be received correctly at the radar installation because of attenuation, scattering, or refraction effects. Moreover, it is possible that the aircraft altitude information derived from Mode C may also be lost or degraded.

\section{Potential mitigating measures}

\subsection{Technical measures}

\section{Moving Target Indicator Processing}

Objects that are moving cause a shift in the frequency of the returned EM energy to the radar receiver; this is known as Doppler shift. Moving target indicator (MTI) processing removes from the display any returned pulses that indicate no movement or are within a specified range of Doppler shift. This removes unnecessary clutter, eliminates unwanted moving targets (such as road traffic), and makes moving targets above a certain velocity more visible.

Rotating wind turbine blades can impart Doppler shift to EM energy reflecting off the blades. Depending on the MTI thresholds set in the radar processor, this may be displayed as a moving target. Changes in wind direction at the turbine, the position of the blade in its rotation, the blade pitch, and other factors may cause the amount of energy returned to the radar on different sweeps to vary. At single turbine sites, a radar return will be repeatedly displayed in the same position and MTI processing can be deployed. However, multiple-turbine sites cause a different effect and MTI processing is much more difficult. On one return, blades from one (or more) turbine(s) may paint on the radar; on the next sweep, the blades of a different turbine may paint. This can create the appearance of radar returns moving around within the area of the wind farm.

On both airport and air defence radar this can appear (depending on the type of radar and the processing thresholds in effect) as unknown aircraft manoeuvring unpredictably. On air defence radar such as those used in the Air Defence Slovak Republic, the overall system may well interpret the activity as an aircraft and automatically start tracking the activity (Wind ... 2002).

\section{Filters}

It is technically possible with many types of radar to filter out returns from a given area to ensure they are not presented on operational displays. This is however at the expense of detecting actual aircraft in the area concerned. In the case of radar that has the ability to discriminate returns in height, it may be possible to filter out only the affected height band. On other radar, all returns in the given area will be lost and, in effect, no overall operational benefit is gained.

\section{Non-Automatic Initiation}

A measure that can be taken within the command and control system to mitigate the effects of spurious radar returns is to establish what is known as a nonautomatic initiation (NAI) area. Within this area, the system does not perform its normal function of automatic track association and correlation. This would prevent the system attempting to correlate the returns from a large number of turbines to form what it perceives to be aircraft tracks. Instead, a human operator monitors the affected area to manually detect genuine aircraft tracks. Whilst this technique can help avoid problems both for surveillance and control of spurious tracks, it can be manpower intensive and requires operator expertise. Furthermore, it cannot help to overcome the effect of clutter on safety. Indeed, the use of clutter filters and NAIs may be operationally mutually exclusive.

\subsection{Operational measures}

The type of operations being conducted and the type of airspace within which a controller is operating are both relevant factors if radar clutter is being experienced.

\section{Controlled airspace}

Within controlled airspace, flight is only possible if approved by an ATC authority. Therefore, controllers should know of all aircraft within that controlled airspace. In this case, if radar clutter is experienced, whether from a wind turbine or other obstacle, the controller may assume that the return is not from an unknown aircraft and will not need to take any action. (There are exceptions to this rule that do not need to be explored here.)

\section{Outside controlled airspace}

Outside controlled airspace (in the Slovak Republic, categorised as Class $G$ airspace), clutter and unknown radar returns present more of a problem. In such airspace, the radar returns of aircraft are the primary means on which the separation of aircraft is based. Clutter must therefore be avoided since it is the only way of ensuring separation from unknown aircraft.

What may occur is that radar clutter from a wind turbine may be interpreted as being a return from an aircraft, or the clutter may be obscuring a genuine radar return from an actual aircraft operating in the vicinity of that clutter.

There are two ways a controller can deal with this problem. The safest option is to simply avoid the area of clutter, usually by a range of 5 nautical miles. Naturally, this is not always possible. Alternatively, the controller may "limit" his radar service by informing the aircraft receiving the service that, due to being in an area of 
clutter, the pilot may receive late or no warning of other aircraft.

Controllers use both methods but each presents its own problem. The cumulative effects of clutter make vectoring to avoid clutter harder and harder. Controllers may be able to cope with one or two areas of clutter, but there is a difficult judgement as to how much proliferation is acceptable. Alternatively, limiting the service is often a last resort, and to admit that clutter may well be obscuring returns from genuine aircraft is a clear indication that flight safety may be compromised.

The significance of unwanted radar returns from wind turbines will depend not only on what type of airspace they are in or underneath, but also on their proximity to traffic patterns and routes. Wind turbines on an extended centreline of a runway are more likely to present a significant problem to controllers at longer ranges due to aircraft lining up for approaches and on departure. Similarly, airports have standard arrival routes (STAR) and standard instrument departure (SID) routes, which may also be considered problematic.

\section{Conclusions}

All radar is different (even if only due to the physical impact of operating locations) and creating a "rule of thumb" for wind farm development near all systems would require a level of generalisation that would probably make it worthless.

Therefore, in considering the effect of wind turbines on radar, developers need to focus on individual radar in the vicinity of their planned development. It is also important for developers to appreciate the nature and extent of any problem. For example, studies in air defence radar that take no account of the associated command and control systems may be of very limited value.

Both civil and military aviation communities have legitimate interests that must be protected, and they include protection against the adverse effects of wind turbines. There is scope for flexibility throughout the process of considering wind farm applications, however. The effects of wind turbines on the physical element of the air domain (as obstructions) are well understood and the procedures for handling them are relatively straightforward. Certainly, a flexible approach to the sitting of turbines can be expected to pay dividends. Developers must, however, bear in mind that there are some locations in which the presence of turbines is unlikely ever to be tolerated.

The effects of wind turbines on electronic systems and the measures that can be taken to overcome these effects are less clear-cut. The sitting of wind turbines will, potentially, affect the radar sensors belonging to both civil and military users in much the same ways, although the operational impact of these effects will probably not be the same. As further research is conducted and experience with existing (and currently approved) wind farms grow, all stakeholders will be able to determine more precisely what may be acceptable and what will not. No matter what, however, this is an area in which early dialogue with the relevant stakeholders is particularly recommended.

\section{Acknowledgments}

This research has been supported by the Scientific Grant Agency of the Ministry of Education of the Slovak Republic and the Slovak Academy of Sciences (VEGA No: 1/0274/08 and KEGA No: 3/5180/07).

\section{References}

Knill, A. 2002. Potential effects of wind turbines on navigational systems (CAA) [online] [cited July 2002]. Available from Internet: <http://www. bwea.com>.

Lewis, R. 2001. Information paper: radar mitigations (CAA), [cited March 2001]. Available from Internet: <http://www.caasrg.com>.

Wind turbines and aviation interests - European experience and practice. 2002. In ETSU W/14/00624 /REP, DTI PUB URN, no. 03/515.

Wind turbines and radar: operational experience and mitigation measures [online]. 2001. [cited December 2001]. Available from Internet: $<$ http://www.bwea.com>.

\title{
VĖJO FERMA IR AVIACIJA
}

\author{
A. Novák \\ S a n trauka
}

Vejjas yra vis didejjantis energijos šaltinis Slovakijos Respublikoje. Jis naudojamas generuoti elektrą turbinomis. Vejjo fermos pagal savo fizikinį dydị ir ypač pagal aukštị gali turèti ịtakos aviacijai. Besisukančios vejjo turbinų mentès gali turèti įtakos tam tikroms aviacijos operacijoms, ypač susijusioms su radarais.

Reikšminiai žodžiai: vėjo ferma, radarų teorija, skrydžių valdymas, komunikacijos navigacija ir priežiūra. 